\title{
Electrical Characteristics of Piezoelectric RF-MEMS Tunable Capacitor
}

\author{
Michihiko Nishigaki Member (Toshiba Corporation, michihiko.nishigaki@toshiba.co.jp) \\ Toshihiko NaganoＮon-member (Toshiba Corporation, toshihiko.nagano@toshiba.co.jp) \\ Kazuhide Abe Non-member (Toshiba Corporation, kazuhide.abe@toshiba.co.jp) \\ Kazuhiko Itaya Non-member (Toshiba Corporation, kazuhiko.itaya@toshiba.co.jp) \\ Takashi Kawakubo Non-member (Toshiba Research Consulting Corporation, takashi.kawakubo@toshiba.co.jp)
}

Keywords : piezoelectric drive, tunable capacitor, MEMS, aluminum nitride, bimorph

Piezoelectric RF-MEMS tunable capacitors are useful components for realizing reconfigurable RF circuit for multi-band mobile terminals. The actuation mechanism of a MEMS tunable capacitor is classified into several types: electrostatic, electromagnetic, electrothermal and piezoelectric actuators. It is thought that piezoelectric actuator is suitable for the mobile terminals due to low voltage and low current operation among these types. In this paper, electrical characteristics of piezoelectric RF-MEMS tunable capacitor are described.

The tunable capacitor having piezoelectric bimorph actuator was formed with AlN as piezoelectric material and $\mathrm{Al}$ as electrode material, which are compatible with conventional CMOS processes, as shown in figure 1. The actuator is driven by the inverse piezoelectric effect of two piezoelectric layers, in which opposite electric fields are applied. Folded beam structure was introduced to cancel curling of the actuator beam due to residual stress of piezoelectric films.

The input signal enters measurement pad, and passes through the fixed electrode. Then the signal passes through the movable electrode of the actuator, and reaches the GND measurement pad via the tunable capacitor. The observed scattering parameters $S_{11}$ are shown in figure 2. Capacitance increased with drive voltage of the actuator, as the movable electrode approached the fixed electrode. Capacitance change ranging from about $0.4 \mathrm{pF}$ to $0.7 \mathrm{pF}$ was observed with driving voltage ranging from $0 \mathrm{~V}$ to $8 \mathrm{~V}$. The tuning ratio of the capacitance was 1.7. The capacitance saturated at $8 \mathrm{~V}$ as the movable electrode contacted the fixed electrode. Q factor increased with $0 \mathrm{~V}$ to $8 \mathrm{~V}$ in spite of increase of capacitance.

The capacitance of the tunable capacitor was larger than that expected from the designed structure at the low voltage range,

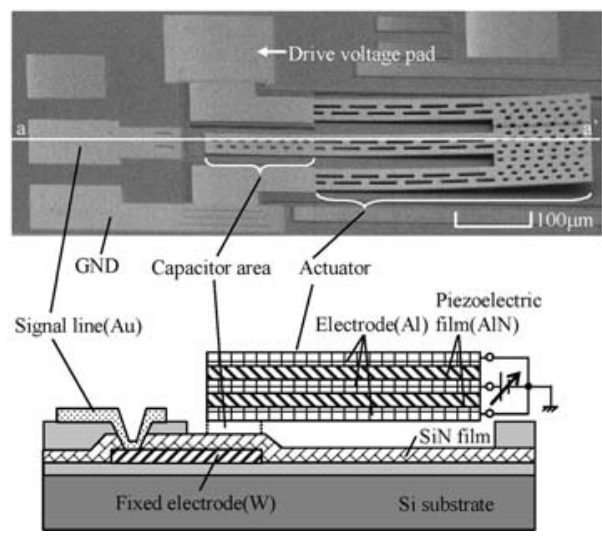

Fig. 1. SEM photograph and schematic cross section of the tunable capacitor while it was smaller than expectation when high voltage was applied in the range of capacitance saturation. In the former case at the lower voltage, the larger capacitance can be attributed to the parasitic capacitance formed between the pad electrodes and the $\mathrm{Si}$ substrate, due to its low resistivity $(\rho \sim 10 \Omega \mathrm{cm})$. In the latter case, the smaller capacitance may indicate incomplete contact between the fixed and the movable electrode, even when high voltage was applied, due to curling of the beam made of the piezoelectric films and the electrode films.

We evaluated net capacitance and $\mathrm{Q}$ factor of the tunable capacitor assuming that the parasitic components due to the pads and the Si substrate can be eliminated using an equivalent circuit model. The estimated $\mathrm{C}-\mathrm{V}$ and $\mathrm{Q}-\mathrm{V}$ characteristics are plotted in figure 3. According to the estimation, the net capacitance of the tunable capacitor changed from $0.20 \mathrm{pF}$ to $0.51 \mathrm{pF}$ with driving voltage ranging from $0 \mathrm{~V}$ to $8 \mathrm{~V}$, exhibiting the tuning ratio of 2.6. Q factor varied from 29 to 11 at the same drive voltage range.

Using of high resistivity substrate and controlling of residual stress of actuator are important to improve electrical characteristics of the piezoelectric RF-MEMS tunable capacitor.

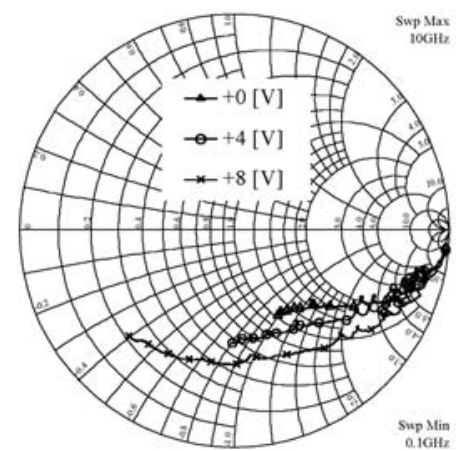

Fig. 2. Measurement result of the tunable capacitor

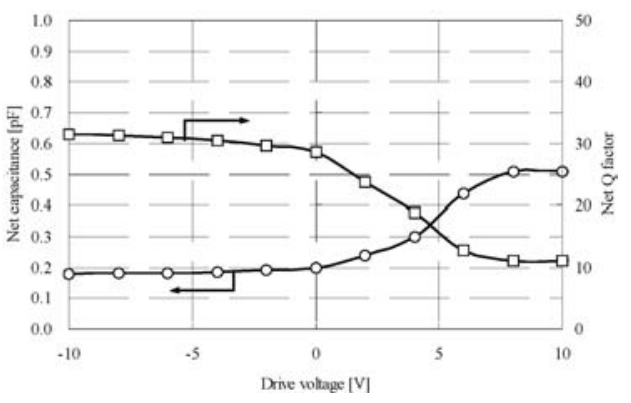

Fig. 3. $\mathrm{C}-\mathrm{V}$ and $\mathrm{Q}-\mathrm{V}$ characteristics at $2 \mathrm{GHz}$ (After subtraction of parasitic element of the pad) 


\title{
圧電駆動型 RF-MEMS 可変キャパシタの電気特性
}

$\begin{array}{llll}\text { 正員 西垣 亨彦* } & \text { 非会員 長野 利彦* } \\ \text { 非会員 阿部 和秀* } & \text { 非会員 板谷 和彦* } \\ \text { 非会員 川久保 隆** } & & & \end{array}$

\author{
Electrical Characteristics of Piezoelectric RF-MEMS Tunable Capacitor \\ Michihiko Nishigaki*, Member, Toshihiko Nagano*, Non-member, Kazuhide Abe*, Non-member, \\ Kazuhiko Itaya*, Non-member, Takashi Kawakubo**, Non-member
}

\begin{abstract}
Piezoelectric RF-MEMS tunable capacitors are useful components for realizing reconfigurable RF circuits for multi-band mobile terminals. In this paper, we describe fabrication process of an AIN RF-MEMS tunable capacitor and electrical characteristics of the tunable capacitor. We chose AlN as piezoelectric material and $\mathrm{Al}$ as electrode material, because these materials are compatible with conventional CMOS processes. The tunable capacitor utilized the piezoelectric bimorph actuator with folded beam structure. The structure of the actuator can cancel curling of the beam due to residual stress of the AlN piezoelectric actuator. After subtraction of parasitic components, net capacitance of the tunable capacitor changed from $0.20 \mathrm{pF}$ to $0.51 \mathrm{pF}$ with drive voltage ranging from $0 \mathrm{~V}$ to $8 \mathrm{~V}$. The tuning ratio was 2.6. Q factor of the capacitor varied 29 to 11 at the same voltage range.
\end{abstract}

キーワード : 圧電駆動, 可変キャパシタ, MEMS, 窒化アルミニウム, バイモルフ

Keywords : piezoelectric drive, tunable capacitor, MEMS, aluminum nitride, bimorph

\section{1. はじめに}

近年，携帯電話などの RF（Radio Frequency）領域を使用 する移動体通信機器は, 1 つの端末で複数の周波数帯の信号 を取り扱うようになり，回路規模が増大しつつある。特に 多くの外付け部品で構成されるフロントエンド回路は高密 度に集積することが難しい。更なる大規模化が予想される フロントエンド回路では可変容量素子として, RF-MEMS デ バイスの応用が期待されている(1)(2)。MEMS 技術を用いて作 製した可変キャパシタやスイッチは，半導体バリキャップ やスイッチと比較して, 原理的に低損失, 低歪であるなど の特徵を持つ(3)。これらの RF-MEMS デバイスをフロントエ ンド回路に用いることで, 使用する周波数帯に応じて回路 素子の值を変化できるため, 回路特性の劣化を抑えつつ, 回路規模の増大を抑制できると考えられている(4)。

我々は RF-MEMS デバイスとして, 圧電体に窒化アルミ

* (株) 東芝 研究開発センター

干212-8582 神奈川県川崎市幸区小向東芝町 1

Corporate R\&D Center, Toshiba Corp.

1, Komukai-Toshiba-cho, Saiwai-ku, Kawasaki 212-8582

**（株）東芝リサーチ・コンサルティング

干212-8582 神奈川県川崎市幸区小向東芝町 1

Toshiba Research Consulting Corp.

1, Komukai-Toshiba-cho, Saiwai-ku, Kawasaki 212-8582
ニウム (以下, AlN と記す) を使用した圧電駆動型 RF-MEMS 可変キャパシタの開発を既に行っており，3Vの駆動電圧で 3 倍の容量変化率を実現している(5)(6)。本研究では作製した 圧電駆動型 RF-MEMS 可変キャパシタの RF 特性の詳細な評 価と解析を行った。

MEMS アクチュエータを駆動する方法として圧電駆動, 圧電体の材料として AlN を使用した理由は以下の通りであ る。MEMS を駆動する方法は, 静電駆動, 電磁駆動, 熱駆 動, 圧電駆動に分類される。これらの駆動方法の駆動電圧 と消費電流の比較を表 1 に示す。静電駆動はアクチュエー タを静電気力により駆動するために比較的高い駆動電圧が 必要である ${ }^{(7)}$ 。また, 電磁駆動と熱駆動はそれぞれ電磁力と

表 1 MEMS の駆動方法の比較

Table 1. Comparison of drive methods of MEMS.

\begin{tabular}{|l|c|c|}
\hline \multicolumn{1}{|c|}{ Drive method } & Drive voltage & Drive current \\
\hline Electrostatic & $\begin{array}{c}\times \\
\end{array}$ & $\bigcirc$ \\
\hline Electromagnetic & $\begin{array}{c}\bigcirc \\
<10 \mathrm{~V}\end{array}$ & $\begin{array}{c}\times \\
\text { A several ten mAs }\end{array}$ \\
\hline \multirow{2}{*}{ Thermal } & $\begin{array}{c}\bigcirc \\
\end{array}$ & $\begin{array}{c}\times \mathrm{V} \\
\text { A several ten mAs }\end{array}$ \\
\hline Piezoelectric & $\begin{array}{c}\bigcirc \\
<10 \mathrm{~V}\end{array}$ \\
\hline
\end{tabular}




\section{表 2 圧電体材料の比較}

Table 2. Comparison of piezoelectric materials.

\begin{tabular}{|c|c|c|}
\hline $\begin{array}{l}\text { Piezoelectric } \\
\text { material }\end{array}$ & $\begin{array}{l}\text { Compatibility to } \\
\text { CMOS process }\end{array}$ & $\begin{array}{l}\text { Piezoelectric } \\
\text { property }\end{array}$ \\
\hline PZT & $\times$ & $\bigcirc$ \\
\hline ZnO & $\triangle$ & $\bigcirc$ \\
\hline AlN & $\bigcirc$ & \\
\hline
\end{tabular}

熱変形によって駆動させるために電磁コイルと抵抗体に電 流を流す必要があり消費電流が大きい( ${ }^{(8)(9)}$ 。このため，これ ら 3 つの駆動方法は，携帯電話などの電池駆動の製品への 適応には不向きである。一方, 圧電駆動は駆動電圧, 消費 電流共に小さく，電池駆動の製品への適応には有利である と考えられる ${ }^{(10)(11)}$ 。なお，圧電駆動でアクチュエータの位 置が切り替わる時間は, アクチュエータサイズにもよるが 数 $\mu \mathrm{s}$ 数 $100 \mu \mathrm{s}$ であり, 静電駆動と大きな違いはないと考え られる。

圧電体にはチタン酸ジルコン酸鉛（PZT）などのペロブス カイト系強誘電体, $\mathrm{ZnO}$ や $\mathrm{AlN}$ などのウルツ鉱型結晶があ る。これらの圧電体薄膜はそれぞれ成膜温度や作製難易度 が異なる。これらの薄膜の CMOS プロセスへの適応性と圧 電性能を比較した結果を表 2 に示す。PZT は圧電性能が非 常に高く各種アクチュエータに使用されているが，成膜温 度が高いため CMOS プロセスへの適応性が悪い。また, $\mathrm{ZnO}$ は CMOS プロセスの温度範囲で良好な特性を得るのが難し い。一方，AlN は PZT と比較して圧電性能は低いが， AlN を使用したデバイスを $\mathrm{Si}$ 上に作製することは容易である(6)。

本論文では，これらの特徵を持つ AlN を用いた圧電駆動 型 RF-MEMS 可変キャパシタの試作結果, 並びに RF 帯にお ける電気特性の評価結果について述べる。

\section{2. デバイス構造と作製プロセス}

〈2・1〉 デバイス構造作製した圧電駆動型 RFMEMS 可変キャパシタ（以下，可変キャパシタと記す）の SEM 像と断面図を図 1 に示す。アクチュエータは 2 層の AlN 圧電体をそれぞれ $\mathrm{Al}$ 可動電極で挟んだバイモルフ構造とな っており，一端は基板に支持され，もう一端は空中に浮い た片持ち梁である。それぞれの圧電体の分極方向は同じで あるため，圧電体に印加する電界をそれぞれ逆方向にする ことで，アクチュエータは逆圧電効果により上下に屈曲変 位する。 $\mathrm{SiN}$ 膜でカバーされた W 固定電極はビアを介して $\mathrm{Au}$ コプレーナ線路の測定パッドに接続されている。キャパ シタ領域はアクチュエータの可動電極と固定電極のオーバ ーラップする領域 $(100 \mu \mathrm{m} \times 50 \mu \mathrm{m})$ で形成される。

図 1 で説明したように, アクチュエータは圧電体と可動 電極を何層にも重ねた構造であるため, 図 2 に示すように, 各層の残留応力の違いにより反りが発生する。図 2 の場合, 可変キャパシタが形成される領域でのアクチュエータの反 り量は $30 \mu \mathrm{m}$ 程度であり, アクチュエータの圧電駆動による 変位と比較して反り量は 1 桁程度大きくなる ${ }^{(6)}$ 。そのため,

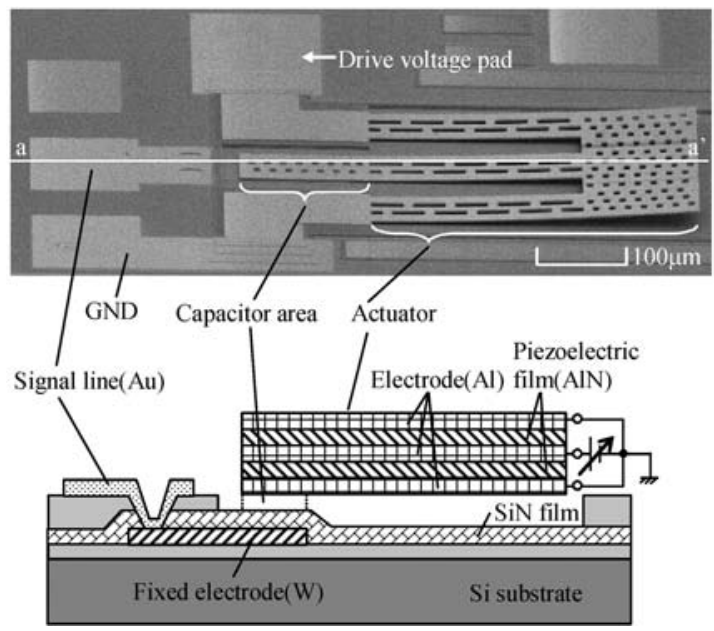

図1 可変キャパシタの SEM 像と断面図

Fig. 1. SEM photograph and schematic cross-section of the tunable capacitor.

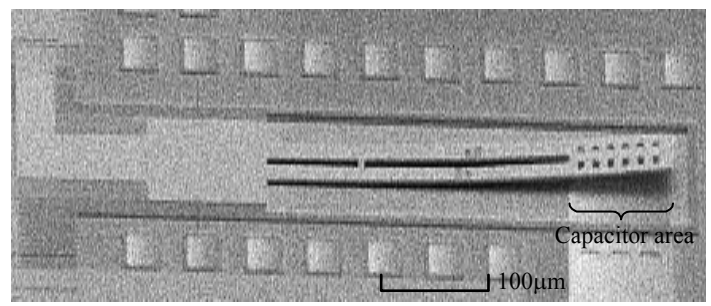

図 2 アクチュエータの反り

Fig. 2. Curling of the actuator.

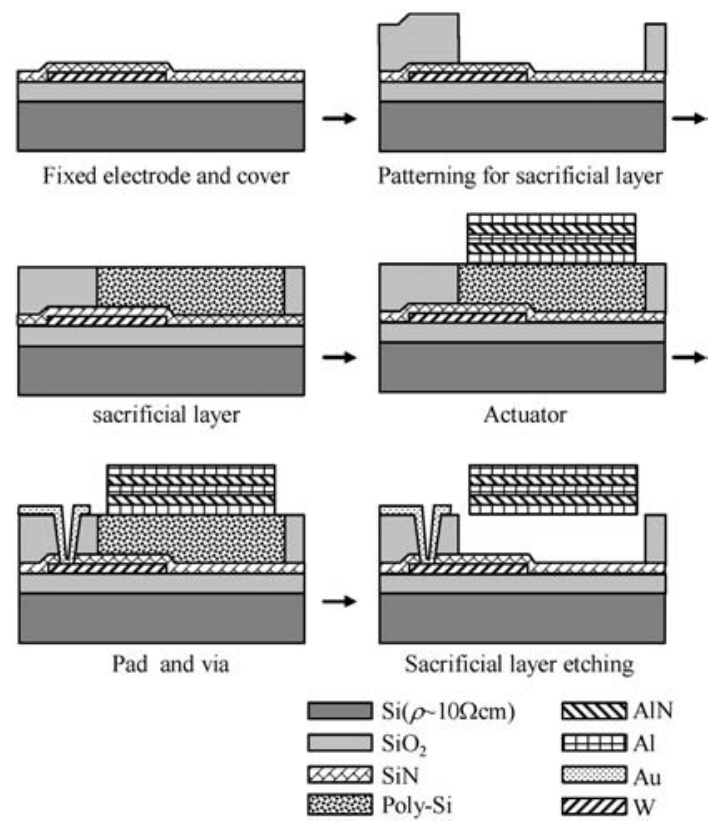

図 3 作製プロセス

Fig. 3. Fabrication process.

駆動電圧に対する可変キャパシタの容量変化率を大きくす ることができないという問題が生じる。

この問題を回避するため, 我々は図 1 に示したように, アクチュエータに折り返し構造を採用した(5)。折り返し構造 
は往路梁と復路梁から成り, 支持端から延びた往路梁を折 り返し, 復路梁で再び元の位置に戻した構造である。往路 梁と復路梁は積層構造, 長さ, 幅がほぼ同じであるため反 り量もほぼ同じである。従って, 往路梁と復路梁が上反り, 或いは平坦である限りは支持端と同じ位置でのアクチュエ ータの反りはほぼキャンセルされ, 結果として可変キャパ シタの容量変化率を大きくすることができる。また，デバ イス作製の際, 各層の残留応力が変化しても反りは同じよ うにキャンセルされるため, 作製条件に依存しない安定し た可変キャパシタを作製することができる。

〈2·2〉作製プロセス 図 3 に可変キャパシタの作製 プロセスを示す(6)。基板には抵抗率が約 $10 \Omega \mathrm{cm}$ の低抵抗 $\mathrm{Si}$ 基板を使用し，表面を熱酸化した後，厚さが $0.2 \mu \mathrm{m}$ の $\mathrm{W}$ 固 定電極を形成し，厚さが $0.2 \mu \mathrm{m}$ の $\mathrm{SiN}$ でカバーする。次に アクチュエータを作製する領域にキャビティを作製し，そ こにPoly-Si 犠牲層を埋め込む。ここで表面はCMP (Chemical mechanical polishing) 法で, 犠牲層の厚さが $1.5 \mu \mathrm{m}$ になるよ うに平坦化する。その後, 厚さ $0.5 \mu \mathrm{m}$ の高配向 $\mathrm{AlN}$ 圧電体 と厚さ $0.2 \mu \mathrm{m}$ の $\mathrm{Al}$ 可動電極からなるバイモルフ構造のアク チュエータをスパッタと $\mathrm{Cl}$ 系ドライエッチングにより形成 した後, 固定電極引き出し用のビア開口と $\mathrm{Au}$ 測定パッドを 形成する。最後に, 犠牲層は $\mathrm{XeF}_{2}$ ガスを用いたドライエッ チングにより除去する。

\section{3. 測定結果と考察}

〈3・1〉測定方法＼cjkstart測定パッドの信号線に印加した信 号は固定電極, キャパシタ領域, アクチュエータの可動電 極を介して GND パッドに伝搬する，いわゆるシャント型の 可変キャパシタである。電気特性はアクチュエータの駆動 電圧に対する，測定パッドの信号線と GND の間の $S_{11}$ パラ メータをベクトルネットワークアナライザ (Anritsu, 37369C）を用いて測定した。

〈3·2〉 測定結果図 4 に駆動電圧に対する $S_{11}$ パラメ ータを示す。図 4 より, 駆動電圧の増加に対して静電容量 が増加し，抵抗值が減少していることが分かる。図 5 には $2 \mathrm{GHz}$ における静電容量と $\mathrm{Q}$ 值の駆動電圧依存性を示す。な お，静電容量と $\mathrm{Q}$ 值は( 1 )式，(2)式を用いて算出した。

$$
\begin{aligned}
& C=\operatorname{Im} Y_{11} / \omega \\
& Q=\operatorname{Im} Y_{11} / \operatorname{Re} Y_{11}
\end{aligned}
$$

ここで $Y_{11}$ は $S_{11}$ パラメータから算出した $\mathrm{Y}$ パラメータであ る。

図 5 より, 駆動電圧が $0 \mathrm{~V}$ から $8 \mathrm{~V}$ で静電容量は約 $0.4 \mathrm{pF}$ から約 $0.7 \mathrm{pF}$ まで変化していることが分かる。容量変化率は 約 1.7 倍である。また，可変キャパシタの Q 值は，同じ駆 動電圧の範囲で, 1.2 から 2.0 まで変化していることが分か る。駆動電圧が $8 \mathrm{~V}$ 以上になるとアクチュエータが $\mathrm{SiN}$ 膜を 介して固定電極に接触するため, 静電容量は飽和する。な お， 1 章でも述べたように，本論文と同じ犠牲層厚で， $3 \mathrm{~V}$ の駆動電圧でアクチュエータが固定電極側に接触する可変 キャパシタは既に報告されている(5)。この構造と比較して本

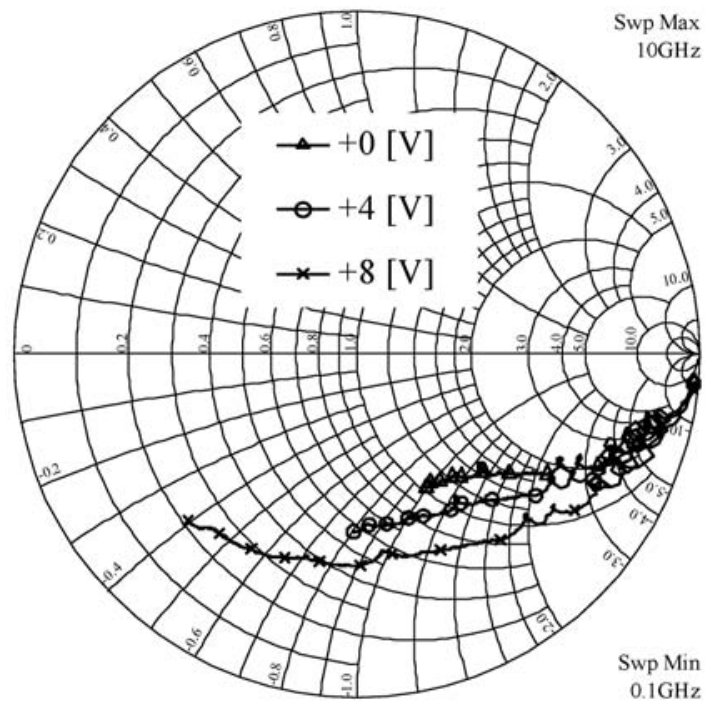

図 4 測定結果

Fig. 4. Measurement result.

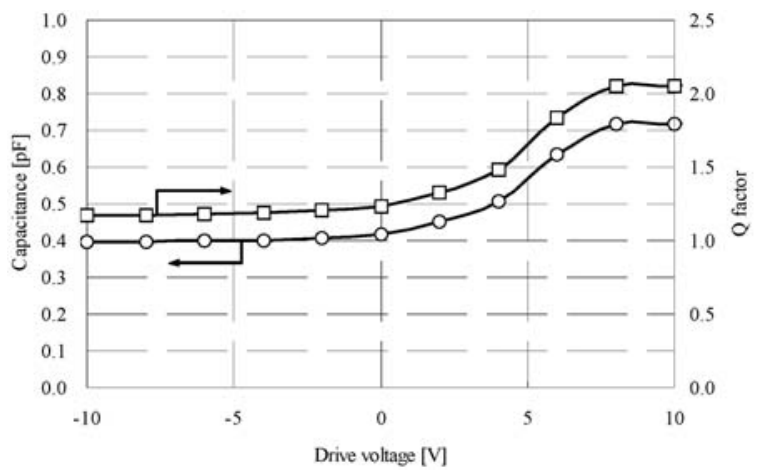

図 $52 \mathrm{GHz}$ における $\mathrm{C}-\mathrm{V}, \mathrm{Q}-\mathrm{V}$ 特性

Fig. 5. $\mathrm{C}-\mathrm{V}$ and $\mathrm{Q}-\mathrm{V}$ characteristics at $2 \mathrm{GHz}$.

論文での可変キャパシタはアクチュエータの長さが半分程 度と短く, 駆動電圧に対するアクチュエータの変位量が小 さいため, アクチュエータが固定電極に接触する駆動電圧 は高くなっている。

静電容量の設計值は, 駆動電圧が $0 \mathrm{~V}$, 即ち固定電極から $1.5 \mu \mathrm{m}$ 上方にキャパシタ領域の可動電極が位置する場合約 $30 \mathrm{fF}$ で, 可動電極の全面が SiN 膜を介して固定電極に完全 に接触した場合約 $1.6 \mathrm{pF}$ である。この場合の容量変化率は 50 倍となる。測定值の静電容量は設計值と比較して, 駆動 電圧が $0 \mathrm{~V}$ のときは大きく, 接触時は小さくなっている。こ の理由は, 前者の場合, 測定パッドの信号線と GND の間の 基板を介した寄生容量も同時に測定されるため，後者につ いては, 可動電極の全面が完全に固定電極側に接触してい ないためであると考えられる。

また, 可変キャパシタの $\mathrm{Q}$ 值は静電容量に反比例するた め, 可変キャパシタの抵抗值が一定ならば静電容量の増加 に対して Q 值は減少するはずである。しかし, 測定值の Q 值は静電容量の増加に対して増加している。これは静電容 量の変化によって見かけの抵抗成分も変化しているためで 


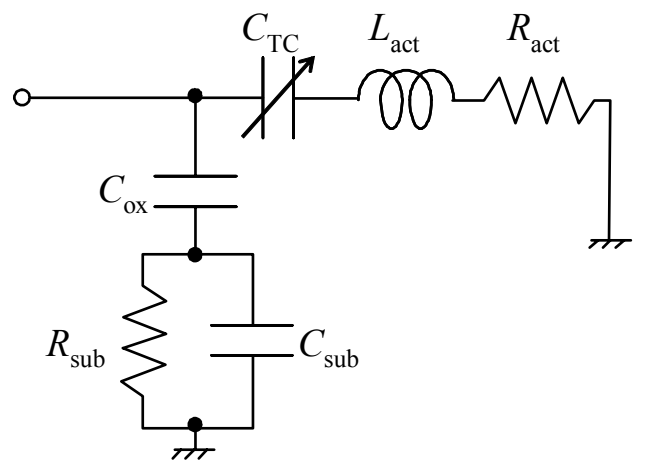

図 6 可変キャパシタの等価回路

Fig. 6. Equivalent circuit of tunable capacitor.

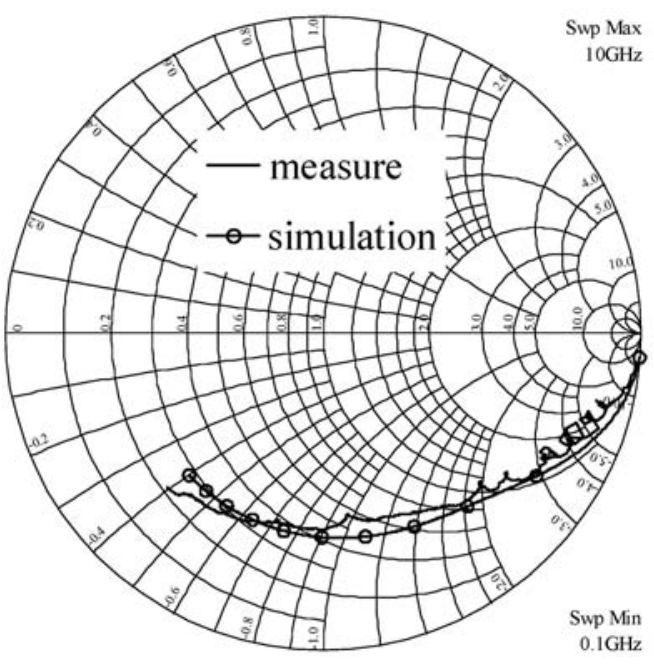

図 7 駆動電圧 $8 \mathrm{~V}$ における測定值と解析值

Fig. 7. Measurement and simulation result at $8 \mathrm{~V}$.

表 3 等価回路パラメータ

Table 3. Parameter of equivalent circuit.

\begin{tabular}{|c|c|c|c|}
\hline$C_{\mathrm{TC}}$ & $0.51 \mathrm{pF}$ & $C_{\text {ox }}$ & $0.67 \mathrm{pF}$ \\
\hline$L_{\text {act }}$ & $0.12 \mathrm{nH}$ & $C_{\text {sub }}$ & $0.04 \mathrm{pF}$ \\
\hline$R_{\text {act }}$ & $14 \Omega$ & $R_{\text {sub }}$ & $198 \Omega$ \\
\hline
\end{tabular}

あると考えられる。

〈3·3〉測定パッドの寄生成分の影響＼cjkstart測定パッドの 寄生成分がキャパシタ領域とアクチュエータから成る可変 キャパシタ単体の特性によ゙の程度影響を及ぼしているの か, また, 可変キャパシタ単体の特性がどの程度であるか を調べるために, 図 6 に示寸等価回路を用いて図 4 に示し た測定結果から可変キャパシタ単体の特性と測定パッドの 寄生成分の影響の切り分けを行った。図 6 において， $C_{\mathrm{TC}}$ は キャパシタ領域における静電容量, $L_{\text {act }}$ と $R_{\text {act }}$ はそれぞれア クチュエータの可動電極のインダクタンスと抵抗， $C_{\mathrm{ox}}$ は測 定パッドから $\mathrm{Si}$ 基板の間の静電容量, $C_{\text {sub }}$ と $R_{\text {sub }}$ はそれぞ れ $\mathrm{Si}$ 基板の静電容量と抵抗である。図 7 , および表 3 には 駆動電圧が $8 \mathrm{~V}$ における等価回路のフィッティング結果, お よびフィッティングパラメータを示す。図 7 より, 測定值

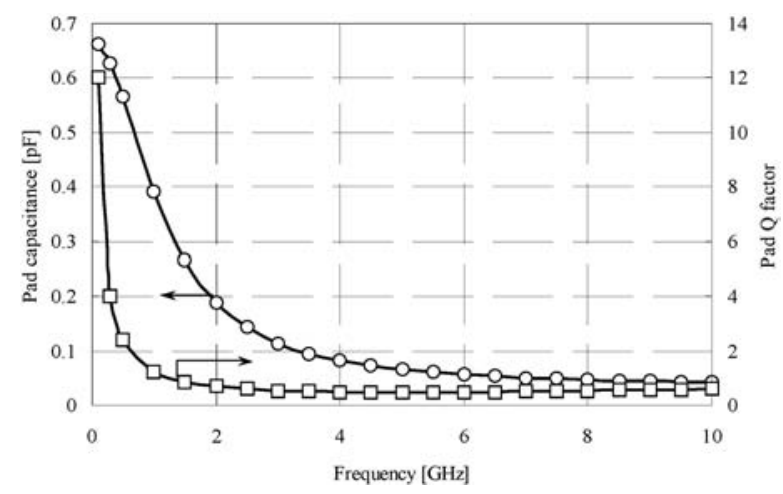

図 8 測定パッドの静電容量と $\mathrm{Q}$ 值

Fig. 8. Capacitance and $\mathrm{Q}$ factor of measurement pad.

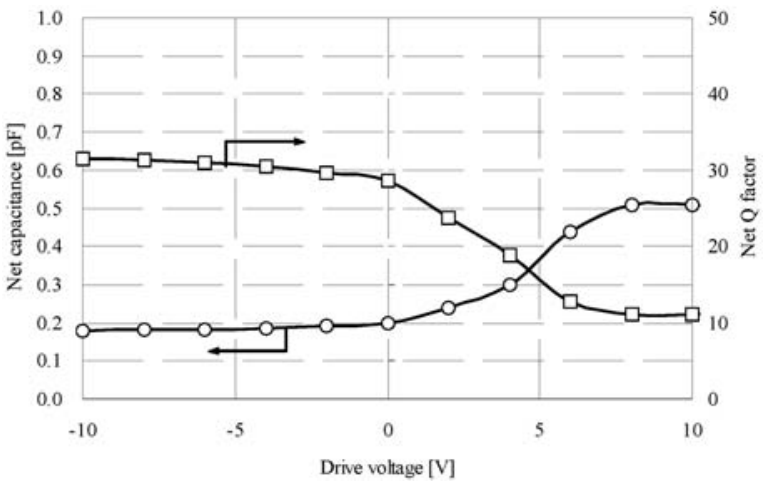

図 $92 \mathrm{GHz}$ における $\mathrm{C}-\mathrm{V}, \mathrm{Q}-\mathrm{V}$ 特性（測定パッドの 寄生成分除去後）

Fig. 9. $\mathrm{C}-\mathrm{V}$ and $\mathrm{Q}-\mathrm{V}$ characteristics at $2 \mathrm{GHz}$ (After subtraction of parasitic components of the measurement pad).

と等価回路のフィッティング結果はほぼ一致していること が分かる。また，パラメータ $R_{\mathrm{sub}}$ と $C_{\mathrm{sub}}$ の間には(3)式の関 係がある ${ }^{(12)}$ 。

$$
R_{\text {sub }} C_{\text {sub }}=\varepsilon_{0} \varepsilon_{\mathrm{r}} \rho
$$

ここで $\varepsilon_{0}$ は真空の誘電率， $\varepsilon_{\mathrm{r}}$ と $\rho$ はそれぞれ基板の比誘電率 と抵抗率である。(3)式と表 3 のフィッティングパラメータ を用いて算出した基板の抵抗率は約 $7 \Omega \mathrm{cm}$ であり実際に使 用した Si 基板の抵抗率とほぼ一致する。そのため, 図 6 に 示した等価回路は可変キャパシタの電気特性を表す妥当な モデルであることが分かる。

図 8 に図 6 の等価回路と表 3 の等価回路パラメータから 算出した測定パッド単体の静電容量と $\mathrm{Q}$ 值を示す。 $\mathrm{Si}$ 基板 での信号は低周波では主に $R_{\text {sub }}$ を流れるが, 周波数が高くな るにつれ $C_{\text {sub }}$ を流れるようになる。そのため, 測定パッド の静電容量は周波数が高くなるにつれ減少する。 $2 \mathrm{GHz}$ にお ける測定パッドの静電容量は約 $0.2 \mathrm{pF}$ であることが分かる。 また, Q 值は周波数にほぼ反比例しており，2GHzにおける 測定パッドの Q 值は約 0.7 である。

可変キャパシタ単体の静電容量の駆動電圧依存性は, 図 6 の等価回路を用いて算出することができ，同時に可変キャ パシタ単体の $\mathrm{Q}$ 值も算出することができる。なお，可変キ ヤパシタ単体の静電容量は図 5 に示した可変キャパシタの 


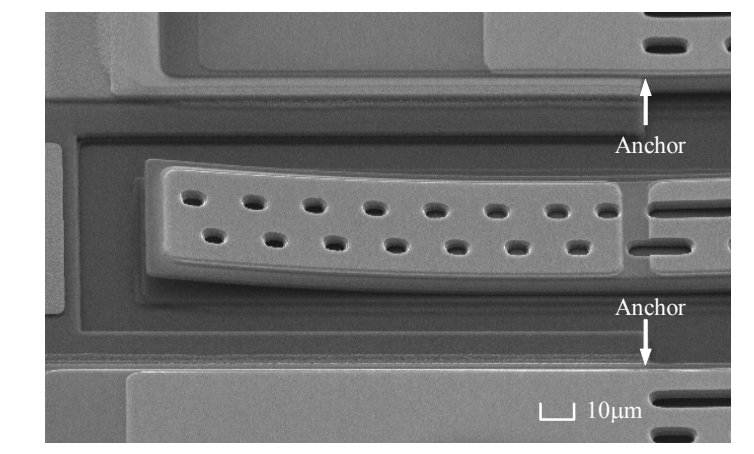

図 10 キャパシタ領域におけるアクチュエータの反り

Fig. 10. Curling of actuator on capacitor area.

特性から図 8 の測定パッドの静電容量を差し引くことでも 算出することができる。

図 9 には図 6 の等価回路を用いて算出した, $2 \mathrm{GHz}$ におけ る静電容量と $\mathrm{Q}$ 值の駆動電圧依存性を示す。測定パッドの 影響を差し引くことにより, 静電容量は全ての駆動電圧で 約 $0.2 \mathrm{pF}$ 減少している。これは図 8 の測定パッド単体の $2 \mathrm{GHz}$ における静電容量とほぼ一致する。駆動電圧が $0 \mathrm{~V}$ から $8 \mathrm{~V}$ で静電容量は $0.20 \mathrm{pF}$ から $0.51 \mathrm{pF}$ まで変化しており, 本来の 容量変化率は 2.6 倍であることが分かる。

駆動電圧が 0V から $8 \mathrm{~V}$ での Q 值は約 29 から 11 まで変化 する。図 5 の測定パッドも含んだ可変キャパシタの $\mathrm{Q}$ 值と 比較すると, 駆動電圧に対する Q 值の振る舞いは逆となっ ている。これは測定パッドの損失がアクチュエータの損失 と比較して大きいためであり, 可変キャパシタ単体の静電 容量が小さいうちは主に測定パッドに信号が流れ, 静電容 量が大きくなるにつれてアクチュエータに信号が多く流れ るようになるためである。

以上のように，絶縁体上に測定パッドを作製しているに もかかわらず, 測定パッドの信号は絶縁体を介して基板を 流れるため, 測定パッドの寄生容量と損失は基板における 静電容量と損失に大きく影響される。この影響は可変キャ パシタをパッケージした場合, 端子の引き出し配線などで も生じる。そのため, 可変キャパシタの特性は可変キャパ シタ単体の特性に加え, 基板に起因した測定パッドや配線 などが及ぼす影響を考慮することが重要となる。測定パッ ドの影響を小さくするには，抵抗率の高い基板や絶縁基板 の使用がある。即ち, 図 6 の $R_{\text {sub }}$ を高くして測定パッドの寄 生容量と損失を低減する方法である。今後, この方法を用 いた可変キャパシタの電気特性向上を図る他に, アクチュ エータの損失をさらに低減する必要があると考えられる。

〈3.4〉 アクチュエータ形状の影響可動電極や圧電 体の残留応力に起因する反りは, アクチュエータを折り返 し構造にすることにより低減できる。しかしながら，完全 に反りがキャンセルされる領域は支持端と同じ位置にある 領域であり, 支持端から離れるに従い再び反りが発生して しまう。

図 10 には図 1 に示した可変キャパシタのキャパシタ領域 を拡大した SEM像を示す。自由端における反り量は約 $10 \mu \mathrm{m}$
であり, 可動電極は一部しか固定電極側に接触することが できず, 結果として接触時の静電容量を大きくすることが できない。〈3・2〉節で述べたように接触時の静電容量の測 定值が設計值と比較して小さい理由は折り返し構造で除去 できなかったキャパシタ領域におけるアクチュエータの反 りの影響であると考えられる。

接触時の静電容量を増加させ, 容量変化率を高くするた めに, 可動電極と圧電体の成膜時における残留応力の低減 や反りの影響を受けにくいアクチュエータ構造の開発が必 要であると考えられる。

\section{4. まとめ}

複数の周波数帯の信号を取り扱う次世代携帯電話などに 有用な, 低電圧, 低消費電流駆動が可能で, CMOS プロセ スへの適応性の高い AlN 圧電体を使用した圧電駆動型 RF-MEMS 可変キャパシタの作製, 評価を行った。アクチュ エータを構成する可動電極と圧電体の残留応力に起因する 反りを抑制するために, アクチュエータには折り返し構造 を採用した。測定パッドの寄生成分を差し引いたときの電 気特性は, 駆動電圧が $0 \mathrm{~V}$ から $8 \mathrm{~V}$ で静電容量の変化は $0.20 \mathrm{pF}$ から $0.51 \mathrm{pF}$ であり, 容量変化率は 2.6 倍であった。Q 值は 29 から 11 に変化した。

低容量時において寄生容量と損失を低減するには基板抵 抗率の増加が必要である。高容量時において静電容量を増 加するにはアクチュエータの反りの低減, 損失を低減する にはアクチュエータの低抵抗化が必要である。

\section{謝 辞}

本研究を行うにあたり, 数多くの意見を頂き, デバイス 作製の一部を行って頂いた，株式会社東芝セミコンダクタ 一社 SoC 研究開発センター石丸一成氏, 大黒達也氏, 池橋 民雄氏，小川悦治氏に感謝の意を表します。

(平成 18 年 9 月 20 日受付, 平成 18 年 12 月 19 日再受付)

\section{文献}

(1) A. Fukuda, H. Okazaki, S. Narahashi, T. Hirota, and Y. Yamano : "A 900/1500/2000-mhz triple-band reconfigurable power amplifier employing RF-MEMs switches", IEEE MTT-S Digest, pp.657-660, Long Beach, CA (2005-6)

(2) C. L. Goldsmith, Z. Yao, S. Eshelman, and D. Denniston : "Performance of Low-Loss RF MEMS Capacitive Switches", IEEE Microwave Guided Wave Lett., Vol.8, pp.269-271 (1998-8)

( 3 ) Th G. S. M. Rijks, P. G. Steeneken, J. T. M. van Beek, M. J. E. Ulenaers, A. Jourdain, H. A. C. Tilmans, J. De Coster, and R. Puers : "Microelectromechanical tunable capacitors for reconfigurable RF architectures", J. Micromech. Microeng., Vol.16, pp.601-611 (2006-2)

(4) T. Clark and C. Nguyen : "RF MEMS in wireless architectures", Proc.ACM/IEEE Design Automation Conference, pp.416-420, San Diego, CA (2005-6)

(5) T. Kawakubo, T. Nagano, M. Nishigaki, K. Abe, and K. Itaya : "Piezoelectric RF MEMS Tunable Capacitor with 3V Operation Using CMOS Compatible Materials and Process", Proc. IEEE IEDM, pp.303-306, Washington (2005-12)

(6) T. Nagano, M. Nishigaki, K. Abe, K. Itaya, and T. Kawakubo : "Fabrication and Performance of Piezoelectric MEMS Tunable Capacitors Constructed with AlN Bimorph Structure", IEEE MTT-S Digest, 
pp.1285-1288, San Francisco, CA (2006-6)

(7) A. Dec and K. Suyama : "Micromachined electro-mechanically tunable capacitors and their applications to RF IC's", IEEE Trans. Microw. Theory Technol., Vol.46, No.12, pp.2587-2595 (1998-12)

(8) M. Ruan, J. Shen, and C. B. Wheeler : "Latching micro magnetic relays with multistrip permalloycantilevers", IEEE Int. Conf. MEMS, pp.224-227, Interlaken, Switzerland (2001-1)

( 9 ) P. Robert, D. Saias, S. Boret, N. Sillon, C. Maeder-Pachurka, P. L. Charvet, G. Bouche, P. Ancey, and P. Berruyer : "Integrated RF-MEMS switch based on a combination of thermal and electrostatic actuation", Transducers, Vol.2, pp.1714-1717 (2003-6)

(10) J. Y. Park, Y. J. Yee, H. J Nam, and J. U. Bu : "Micromachined RF MEMS tunable capacitors using piezoelectric actuators", IEEE int. Microwave Symp., pp.2111-2114, Phoenix, AZ (2001-5)

(11) G. Klaasse, R. Puers, and H. A. C. Tilmans : "Piezoelectric versus electrostatic actuation for a capacitive RF-MEMS switch", Proc. SeSens, Veldhoven, pp.631-634, The Nederland (2002-11)

(12) 谷口研二：「CMOS アナログ回路入門」, pp.86-87, CQ 出版株式会社 (2005)

西 垣 亨 彦

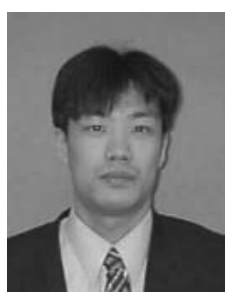

長 野 利 彦

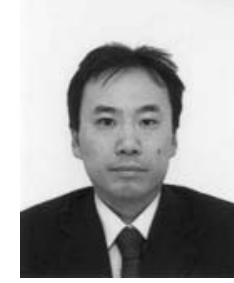

阿 部 和 秀

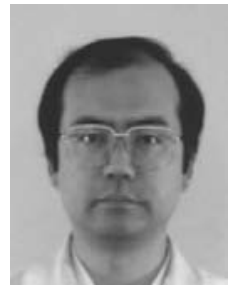

（非会員）1984 年 3 月東京工業大学電子物理学 専攻修士課程修了。同年 4 月（株）東芝入社。 圧電材料, 強誘電体材料の薄膜形成と応用開発 に従事。応用物理学会会員。

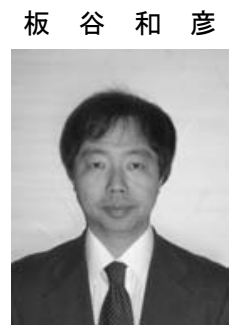
光半導体デバイスや RF-MEMS の開発に従事。 応用物理学会会員。
（非会員） 1966 年 9 月 7 日生。1993 年 3 月東 京大学工学系大学院超伝導工学専攻修士課程 修了。同年 4 月（株）東芝入社。超伝導ジョセ フソン素子や RF-MEMS の開発に従事。主に AlN 系 MEMS の設計からプロセスを担当。

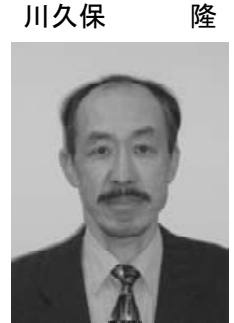

(非会員) 1986 年東京大学理学系大学院相関理 化学修士課程修了。同年（株）東芝入社。1993 年〜1995年カリフォルニア大学サンタバーバ ラ校客員研究員。光半導体デバイス・材料や MEMS $の$ 開発に従事。応用物理学会, 研究・技 術計画学会会員, 工学博士。 